\title{
FUTURE ENTREPRENEURS' EXPECTATIONS BASED ON THE EXAMPLE OF WROCLAW UNIVERSITY OF SCIENCE AND TECHNOLOGY STUDENTS ${ }^{1}$
}

\begin{abstract}
The main thesis of this paper assumes that future entrepreneurs' salary expectations may be the most important reason for them to attend entrepreneurship education and begin business activity. The main aim of this article was to analyse future entrepreneurs' salary expectations with comparison to other students' and graduates' salary expectations and needs towards their first employer, then check the influence of entrepreneurship education on this expectations. However the entrepreneurship intention can be changed by different choice of individual career path to become rather an employee than an entrepreneur. Therefore entrepreneurship education may be also an important factor of this choice. The paper presents results of surveys conducted among the students of the Wroclaw University of Science and Technology in years $2014(\mathrm{~N}=$ 971), $2015(\mathrm{~N}=1241), 2016(\mathrm{~N}=1320)$, and $2017(\mathrm{~N}=1262)$. This wide time span of research combined with the large group of students and graduates gave also a very close view to the future entrepreneurs' expectations towards state's institutions and support. However results are only representative for researched university. Students and graduates of Wroclaw University of Science and Technology undertake professional activity, every year more often both as entrepreneurs and employees. In both cases they are rarely able to accurately assess the value of their qualifications. Future entrepreneurs are driven to become successful business owners because of the sense of personal achievement it provides and for financial stability, according to presented in this paper research.
\end{abstract}

Keywords: entrepreneurship, expected net salary, student survey.

1 The paper has been developed within the framework of the research project number MPN 0402/0071/16 funded form the resources of the Faculty of Computer Science and Management at Wroclaw University of Science and Technology. 


\section{Streszczenie}

\section{Oczekiwania przyszłych przedsiębiorców na przykładzie studentów Politechniki Wrocławskiej ${ }^{2}$}

Podstawowa teza niniejszego artykułu brzmi: oczekiwania płacowe przyszłych przedsiębiorców są najważniejszą determinantą ich zainteresowania edukacją przedsiębiorczą i następnie rozpoczęcia działalności gospodarczej. Głównym celem artykułu było przeanalizowanie oczekiwań płacowych przyszłych przedsiębiorców w porównaniu do oczekiwań i potrzeb pozostałych badanych w zakresie wynagrodzeń wobec pierwszego pracodawcy, a następnie sprawdzenie wpływu kształcenia w zakresie przedsiębiorczości na te oczekiwania. Zauważyć należy, że deklarowana intencja co do rozpoczęcia własnej działalności gospodarczej może ulec zmianie przez wybór innej ścieżki kariery. Dlatego edukacja w zakresie przedsiębiorczości może być również ważnym czynnikiem tego wyboru. W artykule przedstawiono wyniki badań ankietowych przeprowadzonych wśród studentów Politechniki Wrocławskiej w latach $2014(\mathrm{~N}=$ 971), $2015(\mathrm{~N}=1241), 2016(\mathrm{~N}=1320)$ i 2017 ( $\mathrm{N}=1262)$. Tak szeroki zakres czasowy badań, w połączeniu z dużą grupą studentów i absolwentów, pozwala na bardzo bliskie spojrzenie na oczekiwania przyszłych przedsiębiorców wobec instytucji i wsparcia państwa. Jednak uzyskane wyniki są reprezentatywne jedynie dla badanej uczelni. Studenci i absolwenci Politechniki Wrocławskiej podejmują aktywność zawodową nie tylko jako cenieni pracownicy, lecz coraz częściej jako przedsiębiorcy. W obu przypadkach rzadko są w stanie dokładnie ocenić wartość swoich kwalifikacji. Zgodnie z przedstawionymi w artykule badaniami, przyszli przedsiębiorcy dążą osiągnięcia sukcesu finansowego, jako właściciele firm, ze względu na poczucie osobistych osiągnięć i stabilność finansową.

Słowa kluczowe: badanie ankietowe, przedsiębiorczość, oczekiwane wynagrodzenie netto.

\section{Introduction}

The elementary functions of each university include educational, research activities [Wiatrak, 2015] and preparation of future entrepreneurs [Wach, 2015]. For students entrepreneurship education provided by universities is one of their very first entrepreneurial involvement and experience [Grodzka, 2013; Kurzawa-Dobek, Sergiel, 2013]. However, many start-up firms find themselves with problems if the founding entrepreneur lacks the combination of skills necessary to be both "idea person" and manager or fails to perceive the vital distinction between the two [Bates, 1990; Baumol, 1990]. The entrepreneur perceives opportunities that other business executives do not see or do not care about [Cuervo, Ribeiro, Roig, 2007]. Therefore, entrepreneurship education provided by universities is crucial for future entrepreneurs, to encourage their potential of growth and equip them in knowledge and tools to make their business successful. Moreover it is crucial for new companies to work with people who can develop business, because of their potential employability [Baruch, Gregoriou, 2017], which includes learning

2 Artykuł powstał w ramach projektu badawczego numer MPN 0402/0071/16 finansowanego ze środków Wydziału Informatyki i Zarządzania Politechniki Wrocławskiej. 
abilities and high expectations towards their own future [Malara, 2006; Balcerak, 2011]. Some of entrepreneurs use popular information that is generally available to produce something new. Basically, the entrepreneur sees a need and then brings together the manpower, materials, and capital required to meet that need. There is no one, specified entrepreneur definition as well as entrepreneurship has a very vast meaning [Low, 2001; Cuervo, Ribeiro, Roig, 2007]. Entrepreneurship is often discussed under the title of the entrepreneurial factors, the entrepreneurial functions, initiative, and behaviour or even entrepreneurial spirit [Cuervo, Ribeiro, Roig, 2007].

The main aim of this article was to analyse future entrepreneurs' salary expectations with comparison to other students' and graduates' salary expectations and needs towards their first employer. In this article future financial entrepreneurs' expectations are analysed by view on the one of main factors affecting their entrepreneurship [Turker, Selcuk, 2009; Malara et al., 2016]. However entrepreneurship education is also important factor to become an entrepreneur. The thesis of this paper assumes that wage or expected income is major reason to become entrepreneur and to participate in entrepreneurial education. Among many indicators, the financial success and expectation are easy to measure as well as their education impact [Malara et al., 2016; Baruch, Gregoriou, 2017]. Salary expectation can be more reliable reason of motivation for transition from entrepreneurial intention into business [Turker, Selcuk, 2009].

Expectations regarding salary expectations were examined among Wroclaw University of Science and Technology students and graduates in years: $2014(\mathrm{~N}=$ 971), $2015(\mathrm{~N}=1241), 2016(\mathrm{~N}=1320)$, and 2017 ( $\mathrm{N}=1262)$. Second type of expectations revealed by this researches is qualitative and is related to young and future entrepreneur's expectations towards public administration dedicated to their support (such as: entrepreneurship incubator, career offices or advisory services, entrepreneurial education). This second non-quantitative expectations are not subject of wider elaboration in this paper, but are briefly mentioned.

The researches were conducted among Wroclaw University of Science and Technology students and graduates, therefore results based on the sample may be representative only in relation to the examined university. This university is not only largest in Lower Silesia region but also is one of top universities in Poland (ranked usually in first five in national ranks). Moreover, university graduates are co-founders of many successful start-ups and companies such as Bankier.pl, Brand 24 or Nasza-Klasa, which are well-known in Poland, and many more who just gain they part of the market.

\section{Young people's entrepreneurship}

Both economic and noneconomic conditions can affect the level of entrepreneurship within any society. Young generation is a certainly one of the resources on which the strategy of building a modern society and country can rely [Szafraniec, 
2011]. The students (age 19-25) and graduates are young people before their 30 or 35 , therefore are a very good starting point for observing what is happening in the whole society. They are like a lens which focuses various problems related to entrepreneurship and business in Poland.

For a young person, the transition from education to work and employment is a very important process [Fic, 2015]. Being successful in this field is essential not only in terms of liberation from parental control (leaving family house, financial independence) but also in terms of following one's life and professional aspirations, ambitions and plans (purchasing a flat, starting a family). Work is not only a source of income, which for some people means a way to survive, while for others a decent and comfortable life. For future entrepreneurs work is also source of satisfaction and an opportunity for personal development [Cuervo, Ribeiro, Roig, 2007]. Above all, it is a condition for self-reliance ad autonomy understood as a possibility to make independent life choices [Szafraniec, 2011]. Remaining unemployed for the young is a source of dissatisfaction, because it makes them stick in difficult state of suspension between dependency on adults and independence, hinders satisfaction of important life needs, and in the end leads to social exclusion.

Somehow young people are forced to be entrepreneurs or to behave entrepreneurial [Kurzawa-Dobek, Sergiel, 2013]. A shift from education to employment is also a difficult process, influenced by complex and not youth-friendly demographic and macroeconomic trends [Fic, 2015]. Despite being increasingly welleducated, young adults (surveys participants) are the members of the group that is mostly affected by the consequences of the 2009-2011 recession. The professional activity indicators are much more favourable for adults than for the young members of modern Polish society [Szafraniec, 2011]. Due to legal provisions and employer's preferences, even those young people who have already set their foot in the labour market cannot expect stable employment [Fic, 2015; Sulich, 2016]. This situation is caused by several factors, and one of them is the disparity between skills acquired as a result of education and the requirements on the labour market. Employers prefer better qualified, more experienced and responsible professionals. Such features are not typical for young people.

It is the young people that lay future foundations for societies - they bring a portion of energy, talent and creativity, make an important contribution as efficient employees, entrepreneurs, consumers a change factor and members of the civil society [Entrepreneurship in Poland, 2015]. There is no doubt that it is the young, ambitious people that provide good and efficient work, upon which depends a better future. The young people, because they are young, keep the simplicity of their perspective and the ability to embark on enterprises seemingly impossible [Szafraniec, 2011; Baruch, Gregoriou, 2017]. Where there are not enough young people, a threat of stagnation arises, of an inability to take risks, a lack of will to spend one's times and effort in the name of some uncertain intentions, business or to become an entrepreneur.

The influence of entrepreneurship education is most of all reflected in future employment and related opportunities and professional activity of the young. 
Numerous researches support the thesis that entrepreneurship education can help entering the job market in the times of recession, can help establish their own businesses [Turker, Selcuk, 2009; Grodzka, 2015; European Commission, 2017]. Moreover this type of education can help avoid a permanent trace on the young generation caused by unemployment.

\section{Entrepreneurship definition}

Entrepreneurship has multiple definitions and it is considered by many authors from different perspectives: economic, psychological, pedagogical, sociological, etc. [Dawidziuk, 2003]. Because of so many definitions there is a distinction between entrepreneurship and enterprise [Kobia, Siklalieh, 2009]. For some authors these two terms mean one and the same thing, while for others, they are quite different [Balcerak, 2011].

Entrepreneurship is the process whereby an individual or a group of individuals use organized efforts and means to pursue opportunities to create value and grow by fulfilling wishes and needs through innovation and uniqueness, no matter what resources are currently controlled [Coulter, 2001]. Most of the such wishes of future entrepreneurs include also measurable profits, represented as salary or income expectations. In this regard entrepreneurship and enterprise are intertwined as a dynamic process of vision, change and creation [Kuratko, Hodgetts, 2004].

Entrepreneurship stimulates society and culture, does not permit a dogmatic perception on the world. Therefore, individual experiences reading the entrepreneurial activity are always intertwined with those of the others, often transgressing imposed patterns and thinking schemes. Businesses should be perceived as places which encourage critical analysis, as potential sources of experiments, creativity and of stimulating initiative.

For some researchers, these terms mean different things and they separate enterprise from entrepreneurship. Enterprise involves measures to encourage individuals to become entrepreneurs and equip them with the necessary skills to make business successful [Mason, 2000]. In essence, enterprise is about spotting opportunities, creating new ideas into working realities [Nixon, 2004]. Enterprise therefore precedes entrepreneurship.

There is a lack of a common definition of entrepreneurship [Balcerak, 2011; Kobia, Siklalieh, 2009], but still ongoing debate is about addressing question: can we develop entrepreneurship among students? How to measure entrepreneurship intention [Turker, Selcuk, 2009] and the transition from student to an entrepreneur? Is entrepreneurship education needed? Answer to this questions can be extremely hard and there are many examples of effective entrepreneurs like Bill Gates or Steve Jobs, which did not attend to any form of entrepreneurship education nor tertiary education [Balcerak, 2011]. Education is not a condition to become enterprising, but some of its elements can be trained or taught, enhanced in manager's simulation games [Turker, Selcuk, 2009; Balcerak, 2011]. Only learning in action (reflection 
in action) gives students the opportunity on the labour market and avoid unemployment problems [Kolb A.Y., Kolb D.A., 2008; European Commission, 2017].

In this article the entrepreneurship is defined as a capacity and willingness to develop, organize and manage a business venture along with any of its risks in order to make a profit. The most obvious example of entrepreneurship is the starting of new businesses. In economics, entrepreneurship combined with land, labour, natural resources and capital can produce profit. This definition was examined in surveys conducted among students and graduates of Wroclaw University of Science and Technology.

Entrepreneurial spirit is characterized by innovation and risk-taking, and is an essential part of a nation's ability to succeed in an ever changing and increasingly competitive global marketplace. Entrepreneurship is considered a way to increase economic welfare and create employment especially in transition countries such as Poland, where free enterprise is emerging. Today's students are tomorrow's potential entrepreneurs. However, there is little understanding of the factors that affect students' motivation of becoming entrepreneurs and the relationship between entrepreneurship education and students' entrepreneurial attitudes towards entrepreneurship.

\section{Chosen economic factors of entrepreneurship}

Certain qualities are necessary in order to succeed as an entrepreneur. Personal traits can be measured for example to estimate how suitable entrepreneurial career is for a person. However, by personal traits, especially measured by a survey it is impossible to estimate who will became an entrepreneur. The group of entrepreneurs and those who intend to be entrepreneurs is very heterogeneous so that they cannot be distinguished by trait studies from one who are not or will not be entrepreneurs. Values and attitudes have an influence on how one will evaluate the pros and cons of entrepreneurship. They channel the perceptions and interpretations, which affect the motivation and orientation. However, values, attitudes and motivation either do not determine whether one will start an own enterprise.

Since entrepreneurship is essentially the promotion of economic change, the same factors that promote economic growth and development account for the emergence of entrepreneurship. There are two kinds of economic factors which are coming from motivation of entrepreneurs and form external conditions. Motivation can be financial or consist of market incentives: new social needs the entrepreneur can attempt to satisfy in new ways. Second is the existence of a sufficient stock of capital to fund new enterprises and institutions that directs capital to people who wish to use it for entrepreneurial projects. To some extent, old wealth is a precognition for new wealth.

One reason economists are paying more attention to small new firms is that they seem to provide most of the new jobs in modern economy of Poland. Self-employ- 
ment can be natural way to build and develop individuals' financial independence, however it is not easy to teach someone how to become entrepreneur. The functions of most people who participate in the process of producing goods and services are fairly self-evident. Although there are many roles in the productive process, there is one specific role that is entrepreneur. It is the hardest to understand, as well as one of the most controversial.

Financial motivation is probably most important for people who become entrepreneurs, and they have also a high need for achievement, or need-achievement [Malara et al., 2016; Baruch, Gregoriou, 2017]. There is also link between this need-achievement and economic growth explained wider by business psychology. People with high need-achievement are distinctive [McClelland, 1971; Szafraniec, 2011] and they like to take risks, though only reasonable ones, and risk stimulates them to greater effort. Therefore, the quantitative factor - net salary expectations were examined among students of Wroclaw university of Science and Technology. Future entrepreneurs are driven to become successful business owners because of the sense of personal achievement it provides and for financial stability, according to presented in this paper surveys results. Possibility of career development combined with entrepreneurship education can bring future entrepreneurs another path in their career [Malara et al., 2016].

\section{Entrepreneurship education in student opinion}

Education is an area which is subject to very important developments bearing on the fate of young people's transition from education to labour market [Fic, 2015]. It is also determined in education that the major part of the young generation sees education as an opportunity to fulfil their aspirations and life goals. Today education is a factor which most intensely differentiates the level and quality of life, the style of functioning in the society, politics and culture as well as health and psychological condition of people.

Young people have feature of the "youth stupidity" which can be leaven for various changes but what is really captivating is "the reality of infinity" - a feeling of life openness, the awareness that "nothing is decided or set by the fortune, the roads are still open and everything is possible" [Szafraniec, 2011]. Therefore, entrepreneurship is a skill that can be learnt and according to the European Commission entrepreneurship education prepares people to be responsible and enterprising individuals. Moreover, this kind of training helps young people to develop the skills, knowledge and attitudes necessary to achieve the goals they set out for themselves [European Commission, 2017].

Entrepreneurship education then in broad definition proposed by OECD are all activities aiming to foster entrepreneurial mindsets, attitudes and skills and covering a range of aspects such as idea generation, start-up, growth and innovation [Fayolle, 2009]. 
Entrepreneurship education consists of real life experience gained in project work, therefore can be also promoted beyond educational institutions to businesses and the wider community. Although this type of education is crucial for entrepreneurs who work within a group or organisation, evidence shows that people with classic entrepreneurial education, taught across all subjects or a separate subject combined with another, are more employable. Young people with entrepreneurship education are more likely to set up their own companies as European Commission states that even up to $20 \%$ of students who participate in a mini-company programme in secondary school will later start their own company. Businesses started by these students are also more ambitious [European Commission, 2017].

Awareness of the significance of employment is present in the life of young people from the moment they take decisions regarding their own education. Nowadays, school are selected first and foremost with a view to ensure future employment and though long term education postpones the moment of commencing employment, young people (19-35 years) becomes well-versed in the requirements of the labour market very quickly and formulates their own opinions [Szafraniec, 2011; Sulich, 2015]. These are not always accurate, however, they present the state of awareness delineating the area of attainable and unwillingly accepted future choices (table 1). Students of researched university attend to obligatory theoretical courses related to entrepreneurial education. The results of conducted survey shows that about one quarter of students and graduates of Wroclaw University of Science and Technology consider to be an entrepreneur.

Table 1.

Opinions regarding employment

\begin{tabular}{|l|l|l|l|l|}
\hline $\begin{array}{l}\text { Which of the following do you con- } \\
\text { sider the best option nowadays? }\end{array}$ & $\mathbf{2 0 1 4}$ & $\mathbf{2 0 1 5}$ & $\mathbf{2 0 1 6}$ & $\mathbf{2 0 1 7}$ \\
\hline Be an employee, or & $62.3 \%$ & $68.2 \%$ & $56.9 \%$ & $62.1 \%$ \\
\hline Be an entrepreneur & $24.9 \%$ & $23.4 \%$ & $27.6 \%$ & $28.3 \%$ \\
\hline Difficult choice & $12.8 \%$ & $8.4 \%$ & $15.5 \%$ & $9.6 \%$ \\
\hline
\end{tabular}

Source: own survey results.

Only a small percentage of young people decides to establish their own enterprises. Reasons underlying such choices are complex (objective and subjective), however that last two years witnessed an interesting change in approaches to employment (Table 1). The attitude towards entrepreneurship can be defined more clearly in the case of environments with good factual backgrounds for running and independent business.

One reason for the increasing interest in entrepreneurship education is the impact of entrepreneurship on economic growth and employment [Audretsch, 
2001; Turker, Selcuk, 2009]. Even though the prevalence rate of entrepreneurship is low; for example, in high-income countries, less than $10 \%$ of the adult population is involved in entrepreneurial activities [Kew et al., 2013]. By promoting entrepreneurship, economies can further generate economic growth and employment. Entrepreneurship education could be one way to increase the prevalence rate of entrepreneurs and, thereby, stimulate economic growth [Rauch, Frese, 2007].

Entrepreneurship education prepares people to be responsible and enterprising individuals. It helps people develop the skills, knowledge, and attitudes necessary to achieve the goals they set out for themselves. Results of conducted surveys also shows that people with entrepreneurial education are more employable. A university education has a significant role in career formation and business development after graduation. Universities are also important as a place of educational service such as advice, which involve transfer of expertise along with ability to use it in practice [Wiatrak, 2015].

The growing entrepreneurship among students is the possibility to transfer knowledge from universities to newly established enterprises and this process is called academic entrepreneurship [Wiatrak, 2015; Wrzecioniarz, 2010]. Transfer of knowledge into practice is higher in the highest levels of pyramid of knowledge, where the group quantity of entrepreneurs is smaller (Figure 1). In top element of pyramid the level of knowledge, its concentration, is highest.

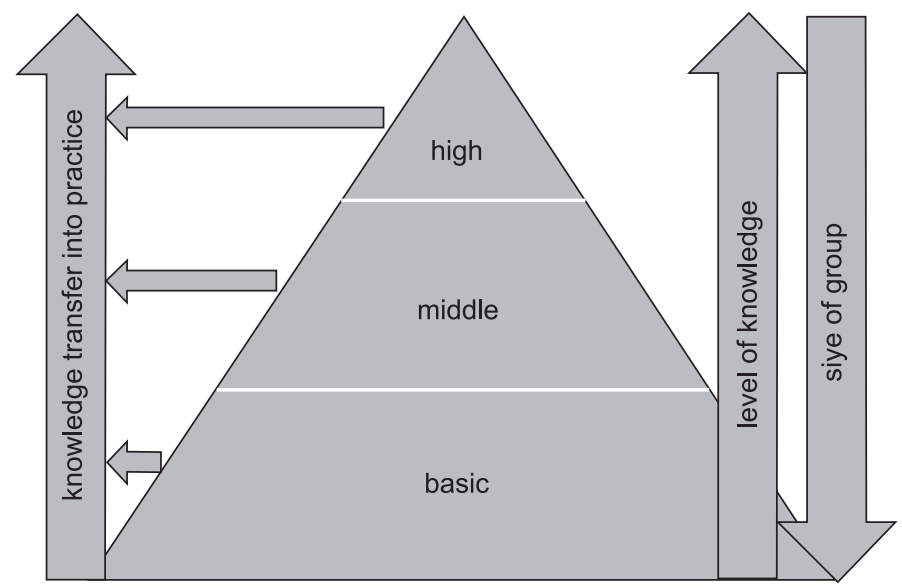

Figure 1. Pyramid of knowledge

Source: based on Wrzecioniarz, 2010.

The group with basic level of knowledge is the largest group (Figure 1). This group has the smallest knowledge transfer to business. Contrary to basic level group is high knowledge level where transfer rate is the highest. Entrepreneurship education among students which possess the highest level of knowledge, can help to transfer new innovative ideas to business and establish new companies 
[Wrzecioniarz, 2010]. The proposed knowledge based economy involves large group of society into tertiary education and proves that entrepreneurship education is important. Picture 1 presents also the role of the universities in whole economy, and their graduates who influence business organisations [Wiatrak, 2015] .

Young people in Poland are very ambitious and want to study at tertiary education level, what shows constantly growing enrolment ratio from 9,8\% in 1990 to $40,9 \%$ in 2009 . Last published data from 2011 shows, that net enrolment ratio was $40,6 \%$ [MNiSW, 2013]. On the other side, unemployment among graduates of Polish universities also is growing since 1990 and was 5,6\% in 2013 [GUS, 2014a]. Observed dynamic changes in domestic job market are a challenge for the whole of employment supporting organizations in public sector - careers offices especially. In Polish job market tensions coming from demographic changes, like the ageing of Polish society and work emigration of young people, also have significant impact.

\section{Chosen surveys results and their discussion}

The surveys were conducted each year between 2014 and 2017 among Wroclaw University of Technology students and graduates to address the question about salary expectations of future entrepreneurs and employees and to reveal their non-salary expectations towards employers. During the surveys students were asked about what type of agreement they want to start their career with and in which area they want to establish their companies. They were asked also to point their salary expectances. Surveys were conducted during 1-month period each (in separate years).

This researches, carried out among students, doctoral students and graduates of Wroclaw of Science and Technology, showed that the will to use professional knowledge to establish own company was declared by about $26 \%$ of all participants ( $8 \%$ within the next year, $12 \%$ within the next two years, $34 \%$ within five years and $46 \%$ in not specified future). Students were definitely more eager to express the intention of having their own company (51\%) than graduates. Students who participated in some form of entrepreneurship were also more eager to start their own business. The main reason for which participants of the research preferred having their own company was the freedom to conduct independent activity - this reason accounted for $63 \%$ of provided justifications $(79 \%$ of students and $52 \%$ of graduates). Majority (81\%) of respondents declared running a company would be connected with fulfilment and satisfaction, which are believed to be significant form of gratification, similarly as the possibility to develop own skills and earn more money. Respondents interested in establishing their own enterprises were aware of the problems connected with running a company. These problems are stress, which they would like to avoid (61\%); and problems which they would be incapable of countering on their own (29\%) or lack of concept for the company. These opinions elucidate significant reasons for which the intention to establish 
one's own company will not translate into real decision in conditions of unstable economy and lack of external support.

These groups are representative groups of each faculty of the university. Most of them $(2014=58,1 \%, 2015=63,2 \%, 2016=64,1 \% 2017=66,8 \%)$ are students of first degree studies, which take 3 years of their studies (before bachelor or engineer degree in Bologna scheme). The rest of students are master students, focused more on their studies and thesis, not involved so much in development of their careers. Some of the students $(2014=38 \%, 2015=12 \%, 2016=8 \%, 2017$ $=2 \%$ ) participated in extra courses organized by Career Service about entrepreneurship (which are not included in a curriculum). The dropping number of participants of this courses was the effect of the arising activity of Wroclaw University of Science and Technology Entrepreneurship Incubator. On the other hand, $31 \%$ of students who participated in the surveys don not want any help form this office or any other, they just want to finish their studies and then start their own businesses. There is a large group of students, which declines $(2014=68 \%, 2015$ $=71,3 \%, 2016=54 \%, 2017=25,3 \%$ ) who never heard about the Academic Entrepreneurship Incubator at Wroclaw University of Science and Technology what was backed by the survey.

The idea of presented in this article pyramid of knowledge (Figure 1) does not work in separated levels of tertiary education (bachelor, master and doctoral studies). Younger students are involved shortly in their thesis (during their $2^{\text {nd }}$ and $3^{\text {rd }}$ year of studies), often they change their supervisor to another ( $2014=42,8 \%, 2015$ $=55 \%$ ) and they change also their master thesis as well. This instability in their interests, was reason to not plan students' careers $(2014=46 \%, 2015=58,2 \%)$ or a reason to change idea of future enterprise profile $(2016=21 \%, 2017=18.8 \%)$.

The significant growth in number of students interested in establishing their own companies was supported also by these of students and graduates who already did it from $1.24 \%$ in 2014 to $6.20 \%$ answers in 2017 can be explained as result of ongoing entrepreneurship education in secondary schools.

Although young students (51\% of survey participants) consider establishing their own companies, this entrepreneurship intention does not mean they really do it in future [Turker, Selcuk, 2009]. For this growing number of students, it is more important to relay on their own companies and create their own work environment with independent rules. In 2014 only 1\% of students were involved in their own business when almost $6 \%$ graduates successfully were self-employed [Sulich, 2015]. The two numbers of self-employed and successfully running their businesses are similar and are about $6 \%$, what means that it is characteristic level of entrepreneurship at this university.

In 2015 year later 3\% of students worked for themselves and also $7 \%$ of graduates of Wroclaw University of Science and Technology declared work in own businesses (Table 2). Students were asked to point their desired amount of money they would like to earn as the entrepreneurs (Table 2). In 2015 young businessmen (students) wanted earn 3875 zlotys (about 934 euro) net but their older colleagues expected exactly 4500 zlotys (1084 euro) net in first month of their activity. The average students' expectations seem to be very carefully fold out, because they 
pointed also to difficulties they have to face during their first few months. The average expected net salary was also increasing among the rest of students from 638 euro (in 2014) to 707 euro (2015) and was lower than expected among the future business owners (Table 2).

Table 2 .

Expected and accepted nett salaries in 2015 among the students and graduates of Wroclaw

University of Science and Technology. Exchange rate between zlotys and euro was on 04.08.2015 equal 4,15 [NBP, 2015]

\begin{tabular}{|l|c|c|c|}
\hline \multirow{2}{*}{ Kind of agreement } & \multirow{2}{*}{$\begin{array}{c}\text { Percentage of } \\
\text { employed }\end{array}$} & \multicolumn{2}{|c|}{ Salary net in euro } \\
\cline { 3 - 4 } & & Expected & Accepted \\
\hline Graduate & $\mathbf{9 8 \%}$ & $\mathbf{7 8 8 , 0 8}$ & $\mathbf{6 5 6 , 8 7}$ \\
\hline Contract work & $3 \%$ & 722,89 & 530,12 \\
\hline Contract of employment & $74 \%$ & 787,51 & 667,04 \\
\hline Contract trainee/internship & $9 \%$ & 883,53 & 771,08 \\
\hline Contract of mandate & $8 \%$ & 662,65 & 506,02 \\
\hline Own business & $7 \%$ & 1084,34 & 783,13 \\
\hline Student & $\mathbf{3 2 \%}$ & $\mathbf{7 0 7 , 4 4}$ & $\mathbf{6 0 0 , 5 5}$ \\
\hline Contract work & $9 \%$ & 765,50 & 767,17 \\
\hline Contract of employment & $24 \%$ & 741,55 & 679,34 \\
\hline Contract trainee/internship & $16 \%$ & 679,64 & 533,07 \\
\hline Voluntary agreement & $3 \%$ & 542,17 & 468,93 \\
\hline Contract of mandate & $44 \%$ & 694,78 & 560,02 \\
\hline Own business & $3 \%$ & 933,73 & 658,63 \\
\hline Average & & 718,48 & 608,59 \\
\hline
\end{tabular}

Source: survey results.

In Table 3 monthly net salary expectations of survey participants in years 2014-2017 in division to entrepreneur graduates and entrepreneur students were compared with average salary expectations of all surveys participants and net statutory minimum wage in euro. Salary expectations in the first month of business activity among both groups of entrepreneurs are double than expected nett average wage declared by all participants of surveys and about four times more than net statutory minimum wage. 
Table 3.

Expected nett salaries declared by students and graduates of Wroclaw University of Science and Technology in euro. Exchange rate between zlotys and euro was on 04.08.2015 equal 4,15 [NBP, 2015]

\begin{tabular}{|l|c|c|c|c|}
\hline \multicolumn{1}{|c|}{ Respondents } & $\mathbf{2 0 1 4}$ & $\mathbf{2 0 1 5}$ & $\mathbf{2 0 1 6}$ & $\mathbf{2 0 1 7}$ \\
\hline entrepreneur graduates & 1237,20 & 1286,16 & 1355,69 & 1459,48 \\
\hline entrepreneur students & 1012,17 & 933,78 & 1209,72 & 1379,28 \\
\hline all participants & 638,05 & 608,59 & 702,01 & 736,67 \\
\hline statutory minimum wage & 298,12 & 309,92 & 326,67 & 351,68 \\
\hline
\end{tabular}

Source: survey results.

Based on results presented in Table 3, it is possible to calculate the Kaitz index which is an economic indicator represented by the ratio of the nominal legal minimum wage to average wage (Table 4). The Kaitz index usually value is about 0,4 and it means that in their first job people prefer more likely to work for a less and with time gaining more experience they expect their wages to rise. Proof of this are results of Kaitz index for all participants salary expectations and classic Kaitz index calculated for Lower Silesia and Poland. The value of Kaitz index about 4,0 indicates also that majority of Polish finds their matching as an employee with their employer.

The classic Kaitz index was calculated according to formula:

$$
\text { Classic Kaitz index }=\frac{\text { statutory minimum wage }}{\text { average wage }}
$$

Table 4.

The Kaitz index calculated for students and graduates of Wroclaw University of Science and Technology based on results and data form Table 3. Nett statutory minimum wage and nett average salary in Lower Silesia economy based on GUS information [GUS, 2014b; GUS, 2015; GUS, 2016]. Exchange rate between zlotys and euro was on 04.08.2015 equal 4,15 [NBP, 2015]. N/A=no data

\begin{tabular}{|l|c|c|c|l|}
\hline \multicolumn{1}{|c|}{ Respondents } & $\mathbf{2 0 1 4}$ & $\mathbf{2 0 1 5}$ & $\mathbf{2 0 1 6}$ & \multicolumn{1}{|c|}{$\mathbf{2 0 1 7}$} \\
\hline Entrepreneur graduates & 0.24 & 0.24 & 0.24 & 0.24 \\
\hline Entrepreneur students & 0.29 & 0.33 & 0.27 & 0.25 \\
\hline All participants & 0.47 & 0.51 & 0.47 & 0.48 \\
\hline Statutory minimum wage & 1.00 & 1.00 & 1.00 & 1.00 \\
\hline Average wage in Lower Silesia & 0.32 & 0.32 & N/A & N/A \\
\hline Average wage in Poland & 0.33 & 0.33 & 0.33 & N/A \\
\hline
\end{tabular}

Source: survey results and own calculations. 
In case of students and graduates salary expectations, to calculate modified Kaitz index the average wage was replaced by them. Then the modified Kaitz index was calculated as ratio:

$$
\text { Modified Kaitz index }=\frac{\text { statutory minimum wage }}{\text { expected } \text { wage }}
$$

The results obtained for all participants suggest that they would like to earn in their first job twice less than average entrepreneur student or graduates. Ratio between entrepreneur graduates salary expectations and statutory minimum wage is during the period of research on the same level, whereas among entrepreneur students it changes and it is always bigger.

For $32 \%$ of students the entrepreneurship education does not lead to enterprise, $56 \%$ of participants see possibility that this kind of education can help in future to set up own business. Only $22 \%$ of students who attended in surveys were convinced that entrepreneurship education is base for enterprise.

Areas of economy which students are interested in their future businesses are presented on Figure 2. Among the area of service $(75 \%)$ most popular are IT companies (40\%) the rest are translations (32\%) and other consulting businesses.

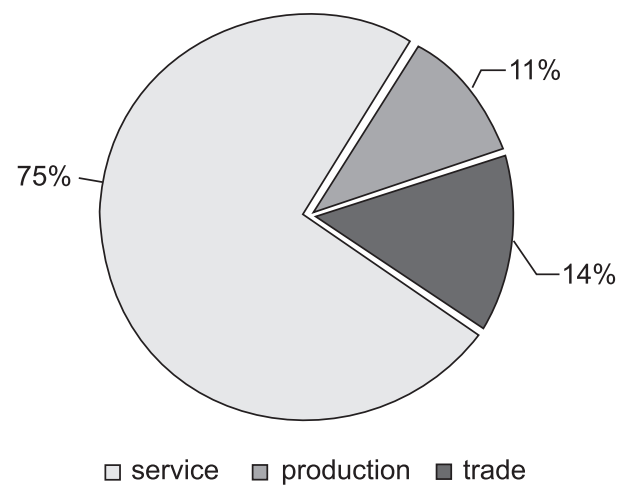

Figure 2. Areas of economy which students are interested in enterprise

Source: survey results.

Popularity of IT business among the participants of survey can be explained by large number of students involved in IT related field of studies $2014=63 \%$ [Sulich, 2015]. Analysis of similar data [Wrzecionarz, 2010] shows that students are even more interested in IT area of services because this kind of business is less capital-intensive. 


\section{Summary}

Young people's potential to innovate is vested in young people's aspirations and life aims, expectations and visions of future employment or self-employment, personal happiness, well-organised society and youth itself and its attributes. The differences between students and graduates are visible in their attitudes and expectations regarding employment, obtained results are similar to many other surveys which aim is to examine salary expectations (for example: Pracuj.pl, Wynagrodzenia.pl or Universum). The younger often dream of a more remarkable career, and would often like to have jobs which guarantee independence (managerial posts, own companies). There are no bigger differences between students and graduates of Wroclaw University of Science and Technology in relations to professional expectations - both groups view salary volume, stability, lack of stress and anxiety, opportunities for personal development and employment stability as most significant. Entrepreneurship is attractive especially for the younger students, but it is rarely element of life plans. The University graduates, who welcome this opinion, state that is burdened with high risk, and they would not be capable of coping with such difficulties on the Polish market. Survey results showed that in recent years certain changes indicating rationalisation of previous preferences regarding life choices of youth have been noted. This concerns both dreams of remarkable careers and professional plans where a slight relative increase in interest in entrepreneurship can be observed.

Students consider self-employment and being entrepreneurial as an alternative way for young people to live in economic freedom, although most of them prefer a contract as employee (Table 2). The growing interest in enterprise among students and graduates backed in survey showed that entrepreneurship education is not always understood as the beginning of their own businesses. Students understand enterprise also in many different ways like scientists and there is not one common definition for them. There is a growing demand to continue entrepreneurship education at Wroclaw University of Science and Technology. The education should be provided for really interested students in form of workshops with cooperation of both offices (at Wroclaw University of Science and Technology Career Office and Entrepreneurship Incubator) and entrepreneurs. This kind of education is probably most beneficial for future leaders and entrepreneurs, even they do not want any help (as declared in survey).

Expectations of future entrepreneurs are growing every year, especially in salaries. If these demands cannot be fulfilled, young people decide more often to run their own businesses. Participants of the surveys that undertake professional activities are rarely able to accurately assess the value of their qualifications (Table 3). On the other hand, it is really surprising that young people interested in own businesses see "the glass ceiling" above them, and do not go out beyond the limits in their income [Szafraniec, 2011]. The explanation of this phenomena can be a certain dose of labour market and business realism, backed by significant number of already established businesses by students and graduates of the university. 
Entrepreneurship education among students which possess the highest level of knowledge, can establish new companies according to proposed the knowledge pyramid concept. This concept as backed by the survey, does not work in separated levels of tertiary education, because of instability of some students which do not plan their careers nor their future.

\section{Bibliography}

Audretsch D. (2001), Research Issues Relating to Structure, Competition, and Performance of Small Technology-based Firms, "Small Business Economics", vol. 16.

Balcerak A. (2011), Przedsiębiorczość i postawa przedsiębiorcza [in:] J. Skonieczny (ed.), Kształtowanie zachowań innowacyjnych, przedsiębiorczych i twórczych w edukacji inżyniera, Indygo Zahir Media, Wrocław.

Baruch Y., Gregoriou A. (2017), The Impact of People Management: Employees' Satisfaction Role in Predicting Financial Performance, "Academy of Management Proceedings", 1.

Bates T. (1990), Entrepreneur Human-capital Inputs and Small Business Longevity, "Review of Economics and Statistics", 72(4).

Baumol W.J. (1990), Entrepreneurship - Productive, Unproductive and Destructive, "Journal of Political Economy", 98(5).

Coulter M. (2001), Entrepreneurship in Action, Prentice-Hall, Upper Saddle River.

Cuervo A., Ribeiro D., Roig S. (2007), Entrepreneurship: Concepts, Theory and Perspective. Introduction [in:] A. Cuervo, D. Ribeiro, S. Roig (eds.), Entrepreneurship: Concepts, Theory and Perspective, Springer, Madrid.

Dawidziuk S. (2006), Czy przedsiębiorczości można się nauczyć? [in:] A.E. Burke (ed.), Modern Perspectives on Entrepreneurship, Senate Hall, Dublin.

Entrepreneurship in Poland (2015), Ministry of Economy, Warsaw, https://www.mr.gov.pl/ media/15459/Entrepreneurship_in_Poland_2015.pdf [access: 09.10.2017].

European Commission (2017), Entrepreneurship education https://ec.europa.eu/growth/ smes/promoting-entrepreneurship/support/education_en [access: 13.10.2017].

Fayoll A. (2009), Entrepreneurship Education in Europe: Trends and Challenges, http://www. oecd.org/regional/leed/43202553.pdf [access: 13.10.2017].Fic M. (2015), Niedopasowanie kwalifikacji i bezrobocie ludzi młodych w Unii Europejskiej, „Problemy Profesjologii”, 2.

Fic M. (2015), Niedopasowanie kwalifikacji i bezrobocie ludzi młodych w Unii Europejskiej, „Problemy Profesjologii”.

Grodzka E.M. (2013), Komercjalizacja wiedzy i ksztattowanie postaw przedsiębiorczych w środowisku akademickim - model polski i amerykański, Zeszyty Naukowe Wyższej Szkoły Bankowej w Poznaniu, t. 50, nr 5.

GUS (2014a), Kwartalna informacja o aktywności ekonomicznej ludności, http://stat.gov.pl/ obszary-tematyczne/rynek-pracy/pracujacy-bezrobotni-bierni-zawodowo-wg-bael/kwartalna-informacja-o-aktywnosci-ekonomicznej-ludnosci-ii-kwartal-2014-r-,2,17. html [access: 15.03 .2017$]$.

GUS (2014b), Obwieszczenie w sprawie wysokości przeciętnego miesięcznego wynagrodzenia brutto $w$ gospodarce narodowej w województwach w $2014 \mathrm{r}$., http://stat.gov.pl/sygnalne/ 
komunikaty-i-obwieszczenia/lista-komunikatow-i-obwieszczen/obwieszczenie-w-sprawie-wysokosci-przecietnego-miesiecznego-wynagrodzenia-brutto-w-gospodarce-narodowej-w-wojewodztwach-w-2014-r-,295,1.html [access: 05.07.2017].

GUS (2015), Obwieszczenie w sprawie wysokości przeciętnego miesięcznego wynagrodzenia brutto $w$ gospodarce narodowej w województwach w 2015 r., http://stat.gov.pl/sygnalne/ komunikaty-i-obwieszczenia/lista-komunikatow-i-obwieszczen/obwieszczenie-w-sprawie-wysokosci-przecietnego-miesiecznego-wynagrodzenia-brutto-w-gospodarce-narodowej-w-wojewodztwach-w-2015-r-,295,2.html [access: 05.07.2017].

GUS (2016), Komunikat w sprawie przeciętnego wynagrodzenia $w$ gospodarce narodowej w 2016 roku, http://stat.gov.pl/sygnalne/komunikaty-i-obwieszczenia/lista-komunikatow-i-obwieszczen/komunikat-w-sprawie-przecietnego-wynagrodzenia-w-gospodarce-narodowej-w-2016-roku,273,4.html [access: 18.10.2017].

Kew J., Herrington M., Litovsky Y., Gale H. (2013), Generation Entrepreneur? The State of Global Youth Entrepreneurship, http://www.youtheconomicopportunities.org/sites/default/files/uploads/resource/GenerationEntrepreneur.pdf [access: 19.03.2017].

Kobia M., Sikalieh D. (2010), Towards a Search for the Meaning of Entrepreneurship, "Journal of European Industrial Training", 34(2), http://dx.doi.org/10.1108/03090591011023970 [access: 19.03.2017].

Kolb A.Y., Kolb D.A. (2008), Handbook of Management Learning [in:] S.J. Armstrong, C. Fukami (eds.), Education and Development, Sage Publications, London.

Kuratko D., Hodgetts R. (2004), Entrepreneurship, Theory, Process, Practice, Thomson South-Western, Stanford.

Kurzawa-Dobek A., Sergiel M. (2013), Percepcja zjawiska przedsiębiorczości na przykładzie polskich i czeskich studentów w latach 2002 i 2012, Zeszyty Naukowe Wyższej Szkoły Bankowej w Poznaniu, t. 50, nr 5.

Low M.B. (2001), The Adolescence of Entrepreneurship Research: Specification of Purpose, "Entrepreneurship Theory and Practice", no. 25(4).

Malara Z., Miśko R., Sulich A. (2016), Wroclaw University of Technology graduates' career paths, "Vesnik Grodzenskaga dzâržanaŭga unìversìtèta ìmâ Ânkì Kupaly. Ser. 5, Èkanomìka, Sacyâlogîâ, Biâlogìâ, t. 6, nr 3.

Malara Z. (2006), Przedsiębiorstwo w globalnej gospodarce, Wydawnictwo Naukowe PWN, Warszawa.

Mason P.L. (2000), Understanding Recent Empirical Evidence on Race and Labour Market Outcomes in the USA, "Review of Social Economy", vol. 58, no. 3.

McClelland D.C., Winter D.G. (1971), Motivating Economic Achievement: Accelerating Economic Development Through Psychological Training, The Free Press, New York.

MNiSW (2013), Szkolnictwo wyższe w Polsce, https://www.nauka.gov.pl/g2/oryginal/2013_0 7/0695136d37bd577c8ab03acc5c59a1f6.pdf [access: 01.02.2017].

NBP (2015), Tabela A kursów średnich - archiwum, http://www.nbp.pl/home. aspx?navid=archa\&c=/ascx/tabarch.ascx\&n=a149z150804 [access: 19.03.2017].

Nixon R. (2004), GEES Enterprise, Skills \& Entrepreneurship Resource Pack, Plymouth.

Rauch A., Frese, M. (2007), Let's Put the Person Back Into Entrepreneurship Research: A Meta-analysis on the Relationship Between Business Owners' Personality Traits, Business Creation and Success, "European Journal of Work and Organizational Psychology", vol. 16. 
Sulich A. (2015), Oczekiwania płacowe studentów i absolwentów Politechniki Wrocławskiej wobec pierwszego pracodawcy, ,E-mentor” 2015, vol. 2(59), http://dx.doi.org/10.15219/ em59.1166 [access: 15.03.2017].

Sulich A. (2016), Wybrane problemy studentów i absolwentów uczelni wyższych Dolnego Śląska na regionalnym rynku pracy po światowym kryzysie z lat 2007-2009, Zeszyty Naukowe Wyższej Szkoły Humanitas. Zarządzanie, t. 17, nr 2.

Szafraniec K. (2011), Youth 2011 Poland, The Chancellery of the Prime Minister, Warsaw.

Turker D., Selcuk S.S. (2009), Which Factors Affect Entrepreneurial Intention of University Students, "Journal of European Industrial Training", vol. 33, no. 2.

Wach K. (2015), Entrepreneurship in the European Union, Cracow University of Economics, Kraków.

Wiatrak A.P. (2015), Issues of a University Advisory System for Regional Development, "International Journal of Contemporary Management", vol. 14, no. 4.

Wrzecioniarz P. (2010), Przedsiębiorczość Akademicka Dolnego Śląska, Media Consulting Agency, Wrocław. 


\section{ROLA RADY RODZICÓW W SKUTECZNYM ZARZĄDZANIU SZKOŁĄ PUBLICZNĄ}

\section{Abstract \\ The Role of Parents' Council in Effective Management of a Public School}

School is a specific public organization. Its difference from other organizations is, among other things, that it brings together specific and diverse stakeholders: students, parents and employees. The implementation of the goals of such an organization depends to a large extent on the director of the educational institution. The conceptual and social skills of the person managing the school have a significant impact on the formation of correct relationships in a diverse environment.

The article attempts to draw attention to the potentially large role of parents' council in managing a public school. The competences of the parents' council were emphasized while showing areas of cooperation with the school's director.

Key words: management in education, management, cooperation, partnership, stakeholders.

\section{Streszczenie}

Szkoła jest specyficzną organizacją publiczną. Jej odmienność od innych organizacji polega między innymi na tym, że skupia ona szczególnych i różnorodnych interesariuszy: uczniów, rodziców oraz pracowników. Realizacja celów tak zbudowanej organizacji zależy w znacznym stopniu od dyrektora placówki oświatowej. Umiejętności koncepcyjne i społeczne osoby kierującej szkołą mają znaczny wpływ na kształtowanie się poprawnych relacji w zróżnicowanym środowisku.

W artykule starano się zwrócić uwagę na potencjalnie dużą rolę rady rodziców w zarządzaniu szkołą publiczną. Podkreślono kompetencje rady, pokazując jednocześnie obszary współpracy z dyrektorem szkoły.

Słowa kluczowe: zarządzanie w oświacie, kierowanie, współpraca/współdziałanie, interesariusze. 